Darko Bosnakovski • Morimichi Mizuno •

Gonhyung Kim · Satoshi Takagi • Masahiro Okumura • Toru Fujinaga

\title{
Isolation and multilineage differentiation of bovine bone marrow mesenchymal stem cells
}

Received: 4 August 2004 / Accepted: 27 September 2004 / Published online: 20 November 2004

C) Springer-Verlag 2004

\begin{abstract}
The bone marrow harbors a population of mesenchymal stem cells (MSCs) that possess the potential to differentiate into bone, cartilage, and fat, and along other tissue pathways. To date, MSCs from various species have been studied. Despite the bovine experimental model being widely used in experiments in vivo and in vitro, only a limited amount of information regarding bovine MSCs is available. The aim of this study was to isolate and induce the multilineage mesenchymal differentiation of bovine MSCs, thereby initiating further research on these cells. Bovine MSCs were isolated from eight calves, and osteogenic, chondrogenic, and adipogenic differentiation was induced by using a combination of previously reported protocols for other species. The level of differentiation was evaluated by histological examination and by analyzing the expression of tissue-specific genes by a quantitative "real time" reverse transcription/polymerase chain reaction technique. Following osteoinduction, the isolated fibroblast-like cells transformed into cuboidal cells and formed alkaline-phosphatase-positive colonies; during differentiation, these colonies transformed into mineralized nodules. In addition, osteogenesis was followed by osteocalcin and collagen type I mRNA expression. Chondrogenesis was confirmed by the demonstration of collagen type II, aggrecan, and sox9 mRNA expression in the cells stimulated by transforming
\end{abstract}

\footnotetext{
D. Bosnakovski $(\bowtie) \cdot$ S. Takagi $\cdot$ M. Okumura $\cdot$ T. Fujinaga Laboratory of Veterinary Surgery, Department of Clinical Science, Graduate School of Veterinary Medicine, Sapporo, Japan

e-mail: darko@vetmed.hokudai.ac.jp

Tel.: +81-11-7065229

Fax: +81-11-7065229

M. Mizuno

Graduate School of Dentistry, Department of Oral Health

Science, Hokkaido University,

Sapporo, Japan

G. Kim

Department of Orthopedic Surgery, Faculty of Medicine, National University of Singapore,

Singapore, Singapore
}

growth factor $\beta 1$ in monolayer culture. After being cultured in an adipogenesis-inducing medium, the MSCs responded by the accumulation of lipid vacuoles and the expression of adipocyte-specific genes. We have therefore demonstrated that cells harvested from bovine bone marrow are capable of in vitro extensive multiplication and multilineage differentiation, making them a relevant and invaluable model in the field of stem cell research.

Keywords Mesenchymal stem cells $\cdot$ Multilineage differentiation $\cdot$ Bovine experimental model

\section{Introduction}

Bone marrow mesenchymal stem cells (MSC) have potential to differentiate into cells with mesenchymal, mesodermal, neuroectodermal or endodermal characteristics (Jiang et al. 2002a, 2002b). In addition, the pluripotent character of adult stem cells present in the muscle, brain, adipose tissue, and dermis of the skin has also been confirmed (Jiang et al. 2002a, 2002b; Zuk et al. 2002; Toma et al. 2001). Pluripotent cells are an attractive promising source in the field of tissue regeneration and engineering, particularly because the use of human embryonic stem cells is limited by ethical considerations (Frankel 2000).

MSCs can be directly isolated from bone marrow aspirates (1) based on their ability to adhere to plastic when plated in a monolayer culture or (2) with micromagnetic beads by using specific antibodies for stem cells (STRO1, CD105; positive selection) or for hematopoetic cells (CD45, GlyA; negative selection; Gronthos and Simmons1995; Majumdar et al. 2000; Reyes et al. 2001). Under appropriate cell culture conditions and stimulation by certain exogenous or endogenous (gene transfer) bioactive factors, MSCs can differentiate into various cell lineages, such as osteocytes, adipocytes, chondrocytes, myocytes, hepatocytes, astrocytes, or neurons (Wang et al. 2003; Lagasse et al. 2000; Woodbury et al. 2000). 
MSCs transplanted into bone and cartilage defects are able to differentiate into osteoblast and cartilage and can repair damaged tissue by newly synthesized bone or hyaline cartilage, respectively (Bruder et al. 1998; Wakitani et al. 1994, 2002; Liu et al. 2002). Similarly, when injected into cardiac muscle, MSCs acquire the phenotype of cardiac myoblasts (Orlic et al. 2001). These characteristics indicate that MSCs can be used as powerful tools in reconstructive medicine.

The apparent plasticity of adult stem cells in vivo may be attributed to de-differentiation, trans-differentiation, or cell-cell fusion (Wagers et al. 2004). Whereas most studies have not sufficiently fulfilled the criteria proposed as the requisite proof of de-differentiation and transdifferentiation (Wagers et al. 2002; Goodell 2003; Rodic et al. 2004), cell fusion has recently been well presented as a mechanism involved in the contribution of transplanted bone marrow cells to liver hepatocytes, cardiac myocytes, and Purkinje neurons (Alvarez-Dolado et al. 2003; Vassilopoulos et al. 2003; Weimann et al. 2003). However, differentiation by cell fusion has been reported to occur only in some types of cells, whereas in other cell types, cell-fusion-independent differentiation has been reported, making all of the presently proposed mechanisms debatable (Ianus et al. 2003; Wurmser et al. 2004).

Ever since Friedenstein et al. (1976) first observed that bone marrow contains fibroblastic cells that are capable of differentiating into bone and adipose tissue, numerous studies have advanced our understanding of the phenotype, physiology, differentiation potential, and possible clinical application of these cells. MSCs used in these studies have been sourced from various species, including humans and small experimental animals such as rat, mouse, and rabbit, and large animals such as dog, cat, pig, and horse (Kadiyala et al. 1997; Martin et al. 2002; Ringe et al. 2002; Fortier et al. 1998; Pittenger et al. 1999). However, limited information regarding bovine MSCs is available, despite the wide application of the bovine experimental model in both in vivo and in vitro experiments, particularly in research on chondrocyte metabolism and cartilage resurfacing.

In the present study, we have isolated bovine MSCs and induced chondrogenesis, adipogenesis, and osteogenesis, thereby establishing a new experimental animal model for this type of research. The use of a large animal experimental model in this type of research provides numerous advantages, particularly prior to the transfer of regeneration technology to human medicine, because large animals are biomechanically more relevant to humans than small experimental animals (Aerssens et al. 1998; Liu et al. 2002; Bosnakovski et al. 2004; Kon et al. 2000).

\section{Materials and methods}

Harvesting and isolation of bovine MSC

Bone marrow was aspirated from eight calves (2-6 months old). The marrow was drawn into syringes containing heparin (1,000 units) and kept on ice until later use. Bovine MSC were isolated by previously described methods (Worster et al. 2000a, 2000b; Mastrogiacomo et al. 2001; Holzer et al. 2002; Bosnakovski et al. 2004). Briefly, the bone marrow sample was washed twice with phosphate-buffered saline (PBS) and twice with Dulbecco's Modified Eagle Medium (DMEM; GIBCO BRL, Grand Islands, N.Y., USA). Following the determination of cell viability and number, nucleated cells $\left(5 \times 10^{4} / \mathrm{cm}^{2}\right)$ were plated in T-75 culture flasks in control medium consisting of DMEM (low glucose) with $100 \mathrm{U} / \mathrm{ml}$ penicillin $\mathrm{G}, 100 \mu \mathrm{g} / \mathrm{ml}$ streptomycin, $0.25 \mu \mathrm{g} / \mathrm{ml}$ amphotericin $\mathrm{B}, 2.4 \mathrm{mg} / \mathrm{ml} \mathrm{HEPES}, 3.7 \mathrm{mg} / \mathrm{ml} \mathrm{NaHCO}_{3}$, and $10 \%$ fetal bovine serum (FBS; lot no. 5300C, ICN, Biomedicals, Ohio, USA). The cells were incubated at $37^{\circ} \mathrm{C}$ in a humidified atmosphere containing $5 \% \mathrm{CO}_{2}$. After being cultured for 4 days, non-adherent cells were removed by changing the culture medium. Following the initial 4 days, which were required for the cells to attach to the flask, the medium was changed every 2-3 days. On day 12 or 13 , the cells were detached by using $0.25 \%$ trypsin in $0.1 \%$ EDTA and either used in experiments or stored by deep-freezing in $10 \%$ dimethylsulfoxide until further use.

\section{Cell proliferation assay}

Proliferation of the cells was assayed by the Hoechst 33258 fluorescent dye technique (Kim et al. 1988). Briefly, the cells, which were cultured in monolayers, were detached by trypsin, collected in a $1.5-\mathrm{ml}$ centrifuge tube, and digested overnight at $60^{\circ} \mathrm{C}$ with papain $(125 \mu \mathrm{g} /$ $\mathrm{ml}$; Sigma, St Louis, Mo., USA) in PBS containing $5 \mathrm{mM}$ EDTA, $5 \mathrm{mM}$ L-cysteine hydrochloride. The amount of DNA was measured in triplicate by using Hoechst 33258 dye (Sigma) in a spectrofluorometer (FP777; Jasco, Tokyo, Japan) with excitation $(365 \mathrm{~nm})$ and emission $(440 \mathrm{~nm})$.

\section{Osteogenic differentiation}

Osteogenic differentiation was induced in the cells from the primary culture and from the first passage by using combinations of previously published protocols in order to enhance the expression of an osteogenic lineage (Jaiswal et al. 1997; Pittenger et al. 1999). In the primary culture (Fig. 1), osteogenesis was initiated from the first day of culturing by using osteogenic medium (Dex), viz., control medium containing $100 \mathrm{nM}$ dexamethasone, $10 \mathrm{mM}$ sodium $\beta$-glycerophosphate, $0.05 \mathrm{mM}$ ascorbic acid (all from Sigma). Bone marrow nucleated cells $\left(5 \times 10^{4} / \mathrm{cm}^{2}\right)$ were plated in T-60 culture dishes. The dishes were divided into two groups based on the culture medium; in one group (Cont), the cells were cultured in control medium alone, whereas in the other group, they were cultured in the osteogenic medium (Dex). The cells were cultured for 24 days with the medium being changed every 
3 days. On day 24, the cells from half of the dishes in each group were exposed to $10 \mathrm{nM}$ 1,25-dihydroxyvitamin $\mathrm{D}_{3}$ (vitamin D; Biomol Research Laboratory, Plymouth Meeting, Pa., USA) added to control or osteogenic medium for three more days, thereby forming the following four experimental groups: control, control + vitamin D, Dex, and Dex + vitamin D (Fig. 1).

To analyze osteogenic gene expression during differentiation, MSCs $\left(3 \times 10^{3} / \mathrm{cm}^{2}\right)$ from the first passage were plated in 6-well plates and cultured until subconfluence (80\%). Subsequently, three experimental groups, namely, the control, Dex, and control + vitamin D groups, were formed based on the culture medium used. Differentiation was closely followed during the 9 days of treatment.

During the experiment, the level of osteogenic differentiation was analyzed by the visualization of alkaline phosphatase (ALP) activity and by the demonstration of mineralized materials in the cell culture by using von Kossa staining. Total RNA was harvested on day 27 (at the completion of the differentiation protocol) from the cells in the primary culture and on days 3, 6, and 9 from the cells treated in the first passage.

Chondrogenic differentiation in monolayer culture

MSCs were plated with a density of $2-5 \times 10^{3} \mathrm{cells} / \mathrm{cm}^{2}$ in 6 -well plates and cultured until the cells reached subconfluence. To induce chondrogenic differentiation, the cells were treated with $1 \mathrm{ng} / \mathrm{ml}$ or $5 \mathrm{ng} / \mathrm{ml}$ transforming growth factor beta 1 (TGF- $\beta 1$; R\&D Systems, Minneapolis, Minn., USA) in plain medium (Worster et al. 2000a, $2000 \mathrm{~b})$. In the control group, the cells were cultured in control medium alone. The level of differentiation was determined by analyzing the expression of cartilagespecific genes by quantitative "real time" reverse transcription/polymerase chain reaction (qRT-PCR) on days 3 and 6 of treatment.

To analyze the effect of various concentrations of TGF- $\beta 1(0,1,5$, and $10 \mathrm{ng} / \mathrm{ml})$ on bovine MSC proliferation, the cells were cultured under the culture

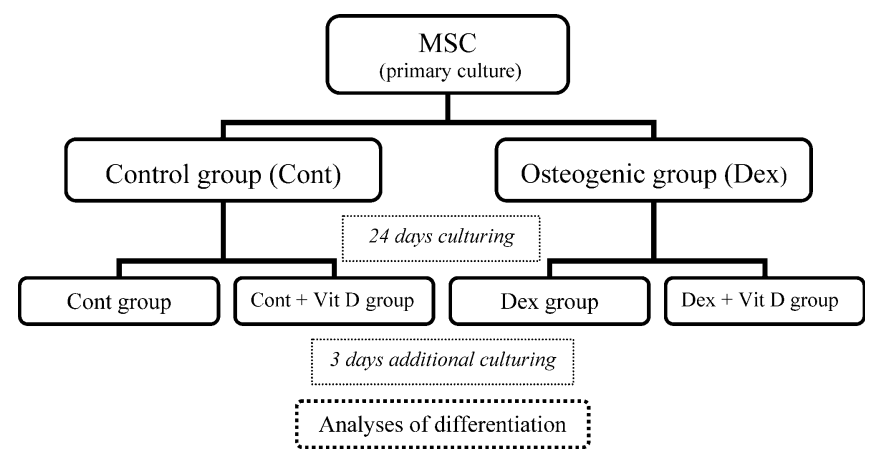

Fig. 1 Scheme of the osteogenic differentiation protocol in primary culture. Cells in the control group (Cont) were cultured in control medium; cells in the osteogenic group (Dex) were cultured in osteogenic medium; cells in the Cont + Vit D and Dex + Vit D groups were cultured in control and osteogenic medium, respectively, supplemented with $10 \mathrm{nM}$ 1,25-dihydroxyvitamin $\mathrm{D}_{3}$ (Vit D) conditions previously described for cell differentiation. Proliferation was analyzed by the measurement of DNA content during the 9 days of treatment.

\section{Adipogenic differentiation}

MSC from the first or second passages were plated at a density of $2-5 \times 10^{3}$ cells $/ \mathrm{cm}^{2}$ in 6-well plates and cultured in control medium until the cell culture reached confluence. At this point, adipogenic stimulation was initiated by culturing the cells in adipogenesis-inducing medium containing DMEM (high glucose, $4.5 \mathrm{~g} / \mathrm{l}$ ), $1 \mu \mathrm{M}$ dexamethasone, $0.5 \mathrm{mM}$ indomethacin, $10 \mu \mathrm{g} / \mathrm{ml}$ insulin, 100 $\mathrm{mM}$ 3-isobutyl-1-methylxantine (all from Sigma), 10\% FBS for 3 days, and for 3 more days in adipogenesismaintenance medium containing DMEM (high glucose, $4.5 \mathrm{~g} / \mathrm{l}), 10 \mu \mathrm{g} / \mathrm{ml}$ insulin, and 10\% FBS. This stimulation was twice repeated (total 18 days treatment; Janderova et al. 2003). The cells in the control group were cultured in control medium (high glucose). The level of differentiation was closely followed by means of a phase-contrast microscope and by histological examination. The expression of the adipogenic-specific genes, peroxisome proliferator-activated receptor gamma 2 (PPAR- $\gamma 2$ ) and adipocyte fatty-acid-binding protein (aP2), was analyzed on day 18 of differentiation.

\section{Histological staining}

The deposition of minerals in the cultures was demonstrated by von Kossa staining. Cell cultures in each experimental group were rinsed twice in PBS, fixed with $3.7 \%$ paraformaldehyde for $15 \mathrm{~min}$, and rinsed three times in distilled water. The cells were stained with $2 \%$ silver nitrate in a dark environment for $10 \mathrm{~min}$ followed by washes and exposure to light for $10 \mathrm{~min}$.

In glutaraldehyde-fixed cells, ALP activity was visualized by the azo-dye method by using naphthol AS-BI phosphate and Fast blue BB salt as the substrate.

Accumulation of the lipid vacuoles was visualized by Oil red $\mathrm{O}$ staining as follows. In brief, $10 \%$ formalin-fixed cells were stained with $0.2 \%$ Oil red $\mathrm{O}$ for $2 \mathrm{~h}$, thoroughly rinsed in water, and counterstained with hematoxylin.

\section{Measurement of mRNA level by qRT-PCR method}

Total RNA was isolated by using Trizol (Invitrogen, Life Technologies, Carlsbad, Calif., USA) in accordance with the manufacturer's instruction. After the samples were treated with DNase to remove possible contamination by genomic DNA, first-strand complementary DNA (cDNA) was synthesized from $2 \mu \mathrm{g}$ total RNA by using M-MLV reverse transcriptase (Invitrogen) with oligo $(\mathrm{dT})_{20}$ as a primer in $20 \mu \mathrm{l}$ reaction mixture. The amount of cDNA was measured by the qPCR method by using the Smart Cycler System (Cepheid, Calif., USA). PCR was carried 
out in a $25-\mu$ final volume containing PCR buffer, $3 \mathrm{mM}$ $\mathrm{MgCl}_{2}, 0.3 \mathrm{mM} \mathrm{dNTP}$ mixture, $0.3 \mu \mathrm{M}$ each of the relevant bovine-specific primer (Table 1), and Taq polymerase (1.25 units/tube; Takara Biomedicals, Otsu, Japan). Forty-five cycles of thermal cycling were carried out at $95^{\circ} \mathrm{C}$ for $5 \mathrm{~s}, 55^{\circ} \mathrm{C}-60^{\circ} \mathrm{C}$ for $15 \mathrm{~s}$, and $75^{\circ} \mathrm{C}$ for $15 \mathrm{~s}$. The amount of PCR product was estimated by measurement of the intensity of fluorescence of SYBR Green I interacting with the PCR product. The mRNA expression level of target genes was normalized by dividing with the mRNA level of glyceraldehyde-3-phosphate dehydrogenase (GAPDH; osteogenesis and chondrogenesis) or $\beta$-actin (adipogenesis). The quality of the PCR products was checked by melting curve analysis and electrophoresis. In addition, the identity of each PCR product was confirmed by sequence analysis (ABI-PRISM 310 Genetic Analyzer; PE Biosystems, Foster City, Calif., USA).

\section{Statistical analyses}

Data from a minimum of four independent experiments were evaluated and expressed as mean $\pm \mathrm{SD}$. An unpaired Student's $t$ test was used to test significance between the two groups. The results were considered significantly different at $P<0.05$.

\section{Results}

Cell culture

MSCs were isolated from bovine bone marrow based on their characteristic property of attaching to plastic culture flasks. The isolated cells that were cultured in monolayer had a bipolar to polygonal fibroblast-like shape (Fig. 2). During monolayer culturing (up to 6 passages) by standard cell culture techniques, no remarkable loss was noted in the cell proliferation potential (data not shown).

\section{Osteogenic differentiation}

Bovine MSCs grown in the primary culture with the osteogenic medium (Dex) formed colonies, and their cellular morphology changed from a fibroblastic shape to a cuboidal form. The cell colonies were found to be ALPpositive on days 12 and 27 of differentiation (Fig. 3a, b). During the culture period, the colonies transformed into mineralized nodules that were demonstrated by von Kossa staining (Fig. 3c). On the other hand, the cells cultured in control medium did not form colonies and retained their fibroblastic shape. A 3-day additional treatment with vitamin D in cell culture had no notable influence on cell shape, ALP activity, or mineralized nodule formation. After 27 days of osteogenesis, significant differences in the expression of collagen type I mRNA were found between the two groups $(P<0.01)$; the expression was 2.8 times higher in the group cultured with dexamethasone

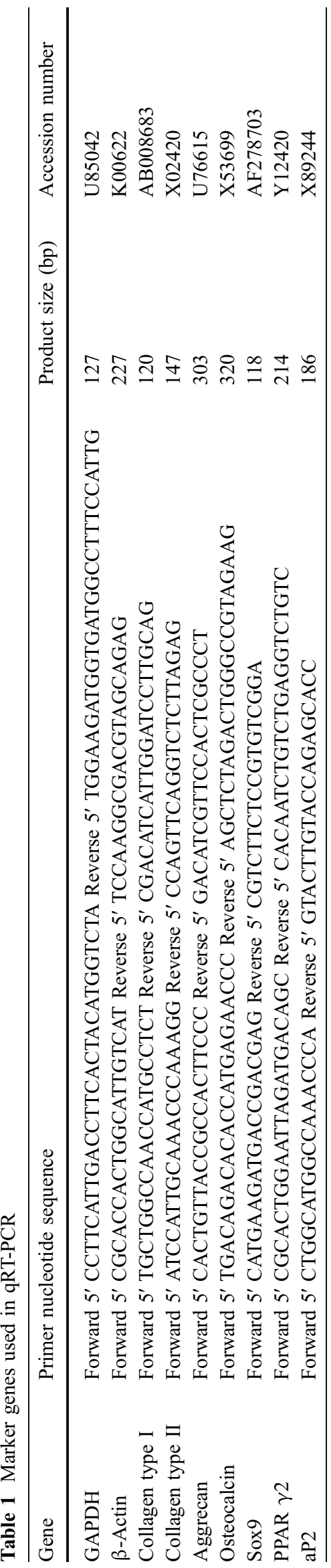




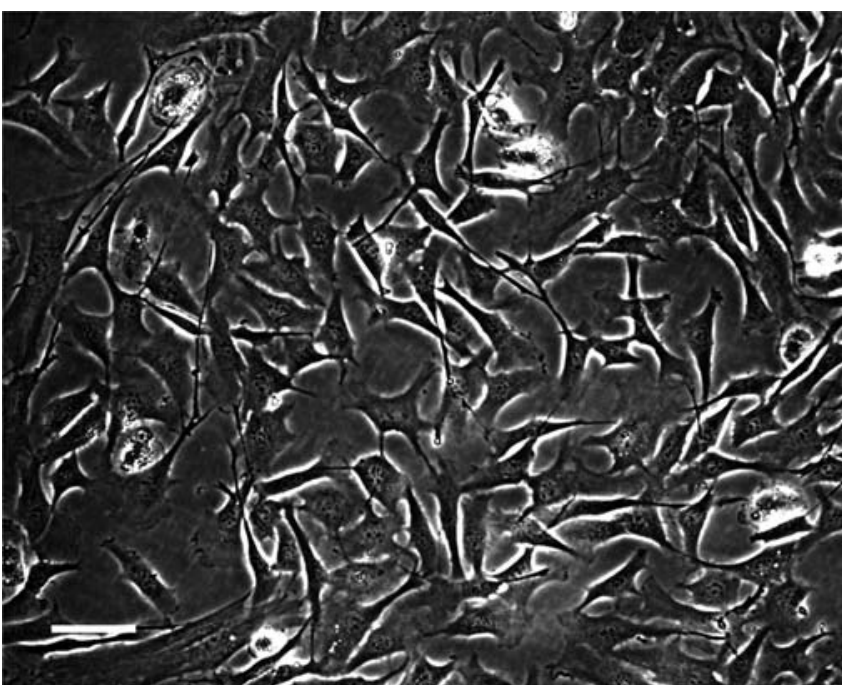

Fig. 2 Morphology of bovine MSCs cultured in monolayer; phasecontrast microscopy. The cells exhibited a fibroblast-like shape. Bar $100 \mu \mathrm{m}$

than in the control group (Fig. 4a). Gene expression of osteocalcin, a typical marker of the osteoblastic phenotype, was only detected in the cells treated with vitamin D (Fig. 4b). In contrast, it was not detected in the cells treated with dexamethasone alone or cultured in control medium for 27 days.

The first-passage cells that were cultured in the osteogenic medium also transformed into cells with a cuboidal-shape; however, colonies and mineralized nodules were not formed. These cells showed 6.9 and 5.5 times higher expression level of collagen type I mRNA on days 3 and 9 , respectively, when compared with the controls $(P<0.01)$. The expression level of collagen type I mRNA in osteogenic medium increased with time and was 1.5 times higher on day 9 than on day 3 of differentiation (Fig. 5a). The cells in the groups treated with vitamin D showed an increased expression level of collagen type I mRNA when compared with the control group; however, this was negligible when compared with the groups treated with dexamethasone. Osteocalcin was detected after 6 days of stimulation of cells with vitamin $\mathrm{D}$, and its

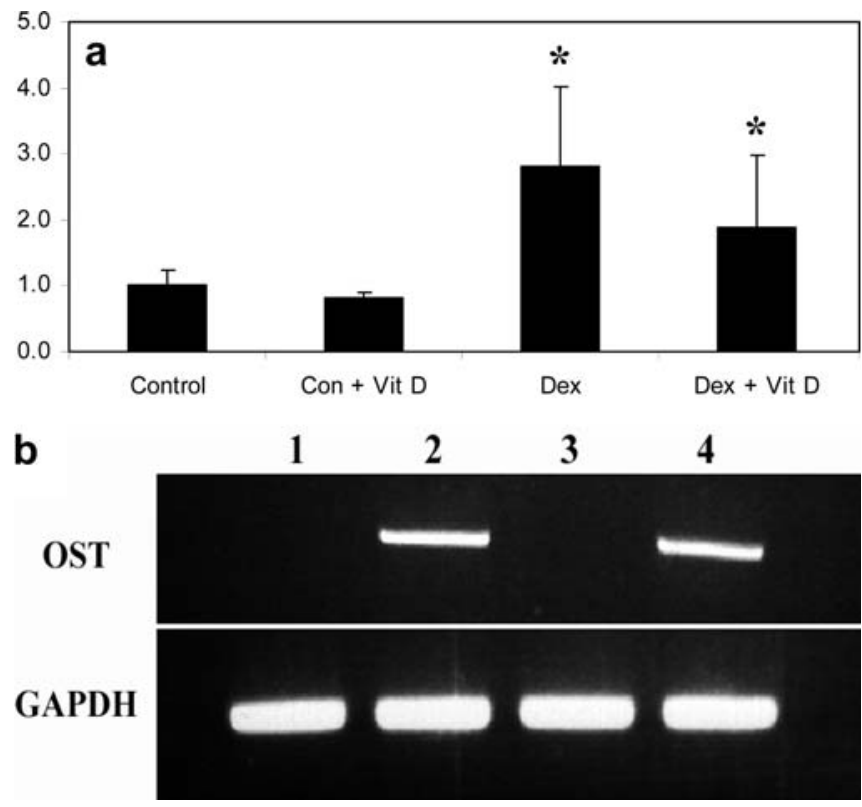

Fig. 4 a Quantitative analysis of collagen type I gene expression by MSCs in primary culture on day 27 in the control (Control), control + vitamin D (Con + Vit D), Dex (Dex), and Dex + vitamin D (Dex + Vit $D$ ) groups. The expression level was normalized with the level of GAPDH mRNA. In the control group, expression of collagen type I mRNA was represented as 1 . Data of four independent experiments were evaluated and expressed as mean \pm SD. ${ }^{*} P<0.05$ when compared with the control group. b Electrophoresis of the PCR products from RT-PCR analysis of osteocalcin (OST) and GAPDH mRNA $(G A P D H)$ expression in cells from primary culture (day 27) in the control (lane 1), control + vitamin D (lane 2), Dex (lane 3), and Dex + vitamin D (lane 4) groups. No osteocalcin was detected in cells untreated with vitamin D for 3 days and in the final stage of osteogenic differentiation.

expression had significantly $(P<0.01)$ increased (by 6.3 times) after 3 days of additional treatment (Fig. 5b).

\section{Chondrogenic differentiation}

Bovine MSCs cultured in monolayer and treated with TGF- $\beta 1$ exhibited a more rounded shape than the cells from the control group. By day 3, cultures treated with TGF- $\beta 1$ showed a prominent increase in cellular density

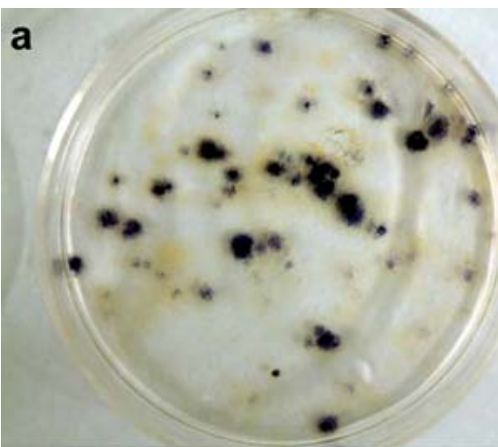

Fig. 3 Osteogenic differentiation demonstrated by histological methods. MSCs cultured in osteogenic medium formed colonies that were found to be positive for alkaline phosphatase (ALP)
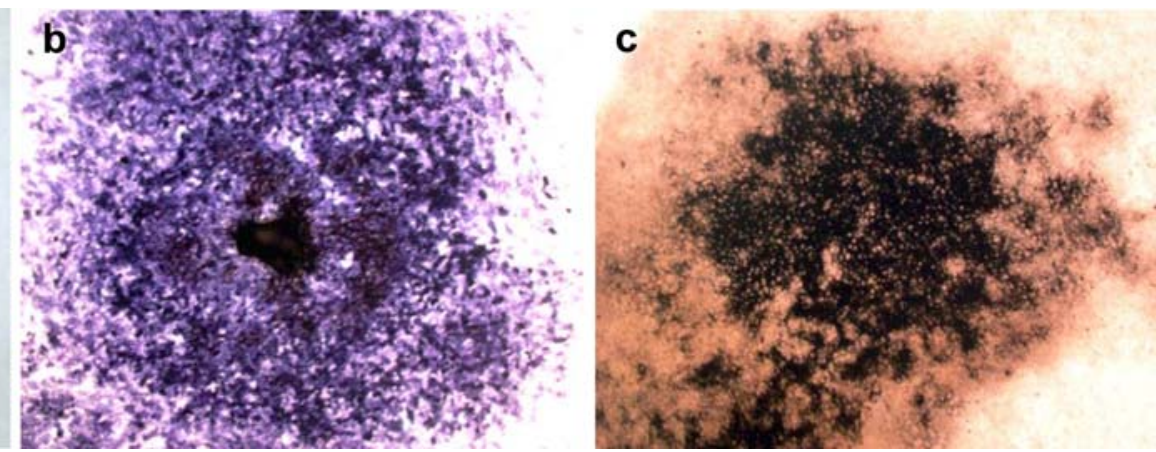

staining (a). During culture, the colonies transformed into nodules that were found to be positive for ALP (b) and von Kossa staining (c) 

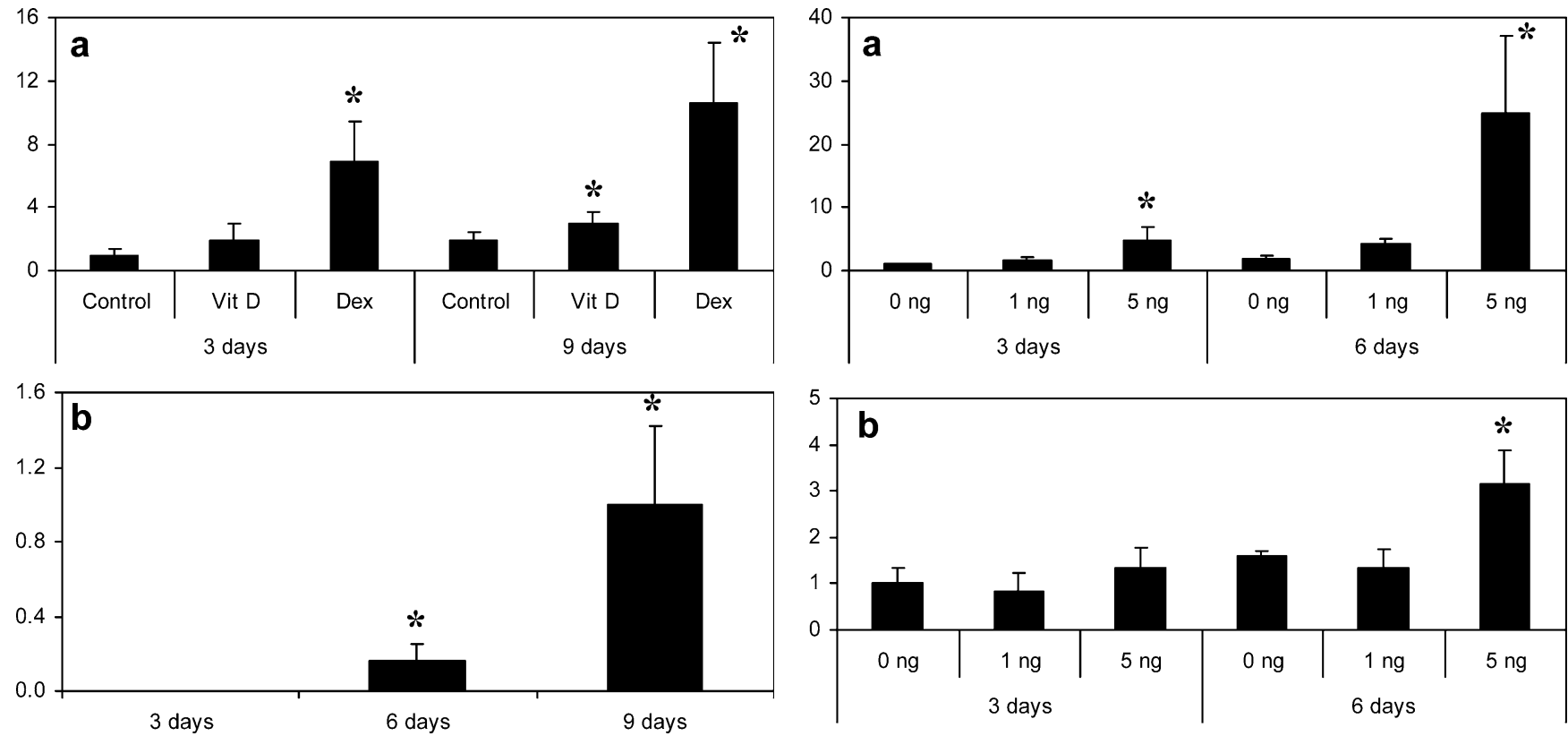

Fig. 5 a Quantitative analysis of collagen type I mRNA in the cells from the first passage in the control (Control), Dex (Dex), and control + vitamin $\mathrm{D}($ Vit $D)$ groups. b Osteocalcin gene expression by MSC from the first passage treated with $10 \mathrm{ng} / \mathrm{ml}$ vitamin D for 9 days. The expression level was normalized for the level of GAPDH mRNA. The expression of collagen type I mRNA in the control group on day 3 and that of osteocalcin in the treatment group on day 9 are represented as 1 . Values are expressed as mean \pm SD. ${ }^{*} P<0.05$ when compared with the control on the same day (a) and on day 3 (b)

with multilayering; this was more pronounced on day 6 . The effect on cell morphology was correlated with the concentration of TGF- $\beta 1$ in the medium. The most pronounced response was observed in cultures treated with $>5 \mathrm{ng} / \mathrm{ml}$ TGF- $\beta 1$. The MSCs started detaching on the second day of treatment with $10 \mathrm{ng} / \mathrm{ml} \mathrm{TGF}-\beta 1$ (data not shown). The detachment was more prominent during the culture period; therefore, this group was excluded from further studies. The expression of chondrocyte-specific genes that occurred following TGF- $\beta 1$ treatment was found to be dose-dependent and time-dependent. Treatment with $5 \mathrm{ng} / \mathrm{ml}$ TGF- $\beta 1$ increased type II collagen expression by 4.7 and 14.2 times on days 3 and 6 , respectively, when compared with the cells cultured in the control groups $(P<0.05$ and $P<0.0001 ;$ Fig. 6a). On day 6 , the expression of aggrecan in the cells treated with $5 \mathrm{ng} / \mathrm{ml}$ TGF- $\beta 1$ was twice that in the control cells $(P<0.01$; Fig. $6 \mathrm{~b})$. Sox 9 , an early marker of chondrogenic differentiation, was detected as early as the third day of treatment with $5 \mathrm{ng} / \mathrm{ml}$ TGF- $\beta 1$. On day 6 , expression increased 5.6 times compared with that on day $3(P<0.05$; Fig. $6 \mathrm{c})$.

The effects of TGF- $\beta 1$ on cell proliferation were also analyzed. After 3 days of treatment with $1 \mathrm{ng} / \mathrm{ml}$ or $5 \mathrm{ng} /$ $\mathrm{ml}$ TGF- $\beta 1$, cell proliferation significantly $(P<0.01)$ increased 1.9 and 2.3 times, respectively, when compared with the controls (Table 2). During the 9 days of treatment with TGF $\beta 1$, the rate of increased proliferation persisted at approximately the same level.

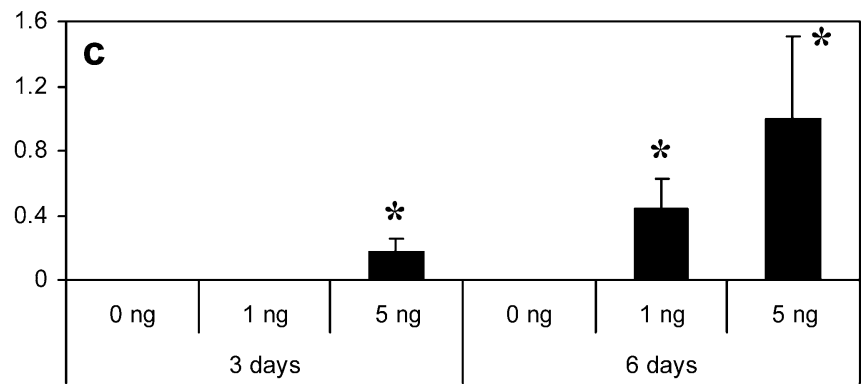

Fig. 6 Quantitative analysis of chondrogenic gene expression by MSCs treated with TGF- $\beta 1$. The expression level was normalized for the level of GAPDH mRNA. The expression of collagen type II (a) and aggrecan (b) in the cells in the control group on day 3 are represented as 1 . The expression of sox 9 (c) in the cells in the group treated with $5 \mathrm{ng} / \mathrm{ml}$ TGF- $\beta 1$ on day 6 is represented as 1 . Data of four independent experiments were evaluated and expressed as mean $\pm \mathrm{SD}$. $* P<0.05$ when compared with the control $(0 \mathrm{ng} / \mathrm{ml}$ TGF- $\beta 1$ ) on the same day

Table 2 Influence of TGF- $\beta 1$ on the proliferation of cells during culture in monolayer for 9 days. The treatment of cell cultures with various concentrations of TGF- $\beta 1$ was started at the stage of subconfluence (day 0). DNA content on day 0 is represented as 1 , and the data is presented as n-fold differences $( \pm \mathrm{SD})$.

\begin{tabular}{lllll}
\hline TGF $\beta 1$ & Day 0 & Day 3 & Day 6 & Day 9 \\
\hline $0 \mathrm{ng} / \mathrm{ml}$ & $1 \pm 0.16$ & $1.14 \pm 0.23$ & $1.46 \pm 0.26$ & $1.96 \pm 0.24$ \\
$1 \mathrm{ng} / \mathrm{ml}$ & $1 \pm 0.16$ & $2.21 \pm 0.30^{*}$ & $3.40 \pm 0.42^{*}$ & $3.56 \pm 0.47^{*}$ \\
$5 \mathrm{ng} / \mathrm{ml}$ & $1 \pm 0.16$ & $2.58 \pm 0.27^{* *}$ & $4.20 \pm 0.46^{* *}$ & $4.24 \pm 0.48^{* *}$ \\
\hline
\end{tabular}

$* P<0.01, * * P<0.001$ when compared with the control group $(0 \mathrm{ng} /$ $\mathrm{ml}$ TGF- $\beta 1$ ) on the same day

\section{Adipogenic differentiation}

Adipogenic differentiation was revealed by changes observed in the cell morphology that followed the formation of lipid vacuoles and by the expression of adipose-specific genes. Following the first induction 
Fig. 7 Adipogenic differentiation of MSCs; Oil red O staining of the cells in the control group on day 6 (a) and in the adipogenesis-induced group (b) after the first adipogenic treatment (3 days culturing in adipogenesisinducing medium followed by 3 days culturing in the adipogenesis-maintaining medium). Small lipid vacuoles were detected in the cells in the treated group (white arrows). Morphology of the cells by phase-contrast microscopy (c) and Oil red $\mathrm{O}$ staining (d) after three cycles of adipogenesis induction (total 18 days) showing the increase in size of the lipid vacuoles, and the typical morphology of adipocytes. Bar $100 \mu \mathrm{m}$
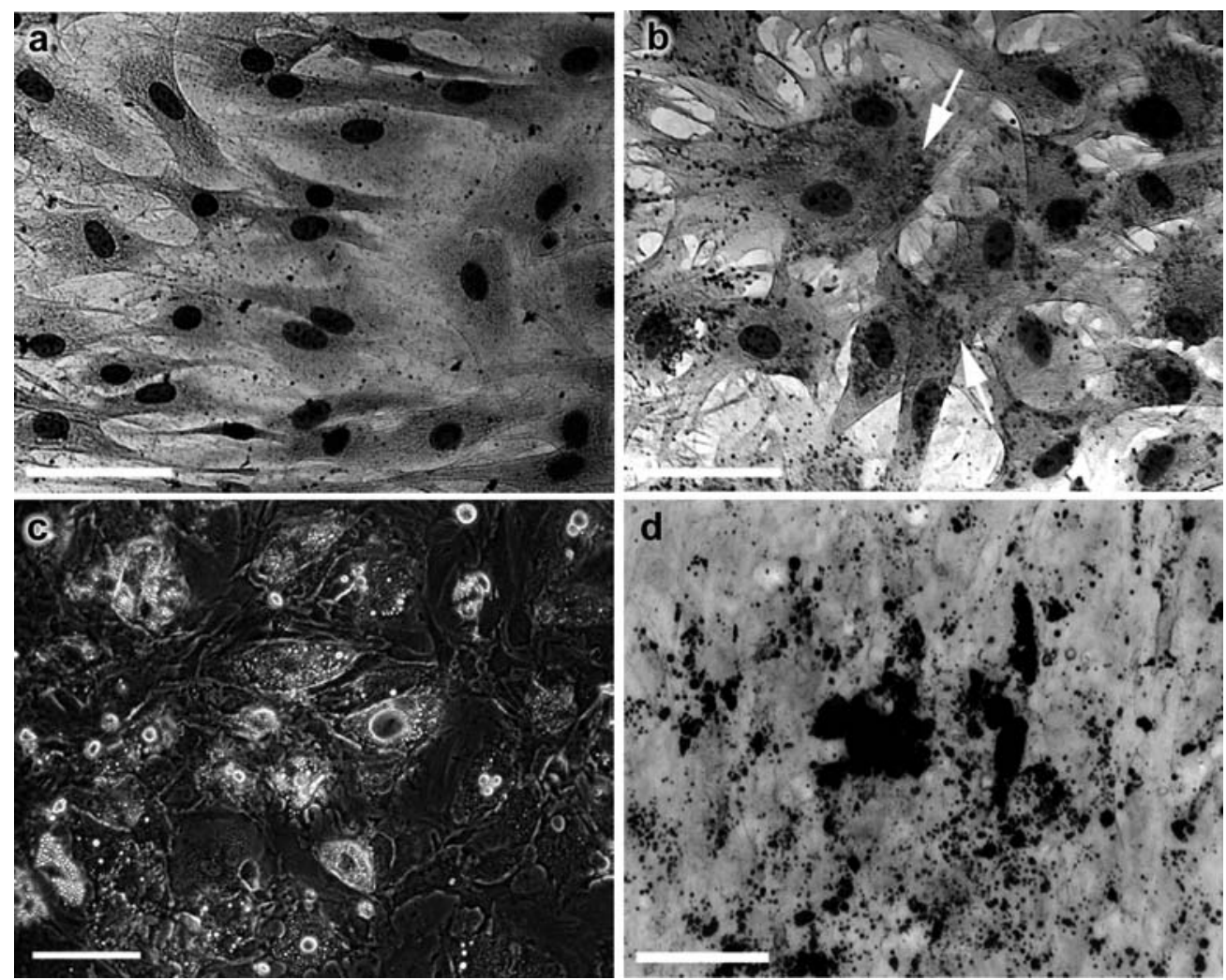

a
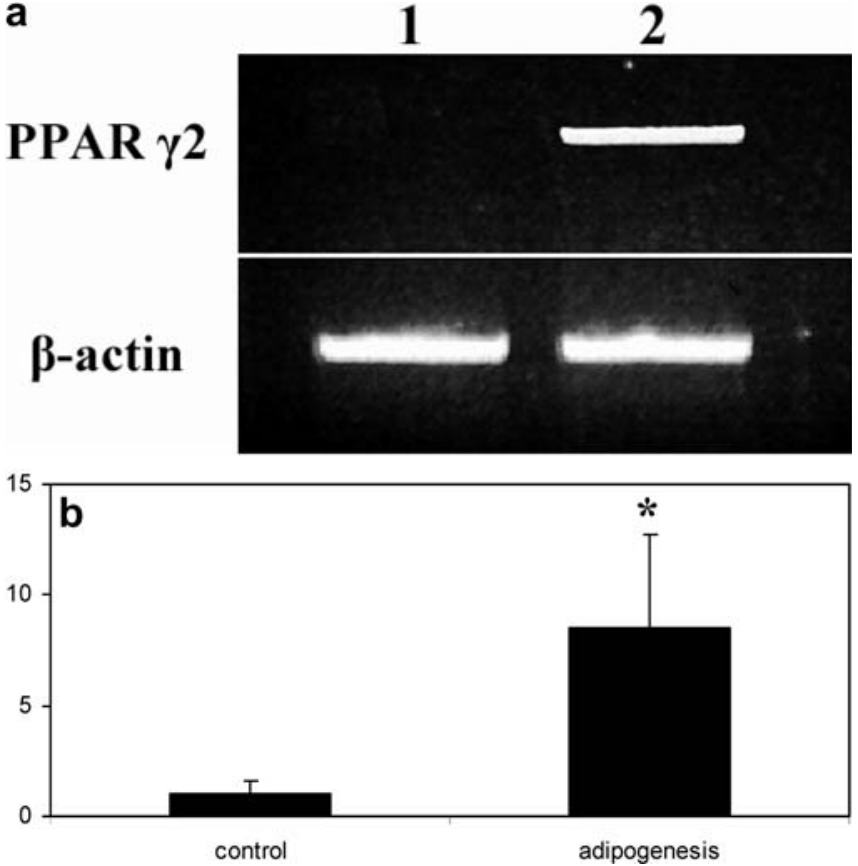

Fig. 8 Gene expression prior to adipogenic differentiation. a Electrophoresis of the PCR products from RT-PCR analysis of PPAR- $\gamma 2$ and $\beta$-actin mRNA expression in the cell culture for 18 days in the control (lane 1) and adipogenesis-induced (lane 2) groups. PPAR- $\gamma 2$ was detected only in the treated cells. b Quantitative analysis of aP2 mRNA expression in the adipogenesis-induced cells and in the control cells on day 18. The expression level was normalized for the level of $\beta$-actin mRNA. The expression of aP2 in the control group is represented as 1 . Data have been expressed as mean $\pm \mathrm{SD} .{ }^{*} P<0.05$ treatment, small vacuoles were observed in the ovaltransformed cells by phase-contrast microscopy. Oil red O staining confirmed that these were lipid droplets (Fig. 7b). The number of vacuoles and their size increased during the culture period, reaching a maximum following the third induction treatment (Fig. 7c, d). After 18 days of differentiation, $50 \%-90 \%$ of the cells contained lipid vacuoles of varying sizes. This estimation was carried out by counting the cells that had acquired an adipocytic phenotype in a minimum of five microscopic fields. On the other hand, cells in the control groups maintained their fibroblastic shape with a sporadic incidence of cells containing small vacuoles stained by Oil red O. On day 18 of differentiation, the expression of adipocyte-specific genes was analyzed by qRT-PCR. Expression of PPAR- $\gamma 2$ was observed only in the adipogenesis-induced cells (Fig. $8 \mathrm{a})$. The expression of aP2 was significantly $(P<0.001)$ increased, viz., 8.4-fold (Fig. 8b), when compared with the control group.

\section{Discussion}

The capability of fibroblast-like cells, isolated from bovine bone marrow, to undergo osteogenic, chondrogenic, and adipogenic differentiation under adequate culture conditions has been demonstrated in the present study. These fibroblast-like cells cells, referred to as MSCs, have been found to be pluripotent, as are their rodent, feline, porcine, and human counterparts. 
The techniques used for the isolation and differentiation MSCs were a combination of those previously used in other species together with minor modifications aimed at achieving a better expression of lineage markers (Ringe et al. 2002; Martin et al. 2002; Heng et al. 2004).

Osteogenesis was confirmed by the presence of the ALP enzyme, a tissue non-specific (bone/liver/kidney/cartilage/ fat) but well-known early osteo-differentiation marker, by the expression of osteocalcin and collagen type I mRNA, and by the mineralization of the matrix. Currently, a definitive marker for cells of the osteogenic lineage is unknown; however, the three criteria mentioned above are widely accepted as being characteristic of osteoblasts (Andrades et al. 1999; Mizuno et al. 2000; Walsh et al. 2003; De Jong et al. 2004; Chen 2004). On exposure to osteoinductive medium, bovine MSCs, like those from other species, transformed from a fibroblastic to a cuboidal shape, thereby exhibiting osteoblastic morphology. In primary culture, changes in the cell morphology were followed by cell growth into colonies and the formation of ALP-positive mineralized nodules, a characteristic of osteogenesis in rat and human MSCs (Mizuno et al. 2000; Bruder et al. 1997) but not in feline or ovine MSCs (Martin et al. 2002; Kon et al. 2000). Bovine MSCs expressed osteocalcin mRNA in response to vitamin D but not to dexamethasone treatment. The same behavior was reported in human MSCs, which when treated with dexamethasone, expressed considerably less osteocalcin than did cells that were not cultured in osteoinductive medium prior to treatment with vitamin $\mathrm{D}$. This could be attributable to the glucocorticoid-induced reduction of vitamin $\mathrm{D}$ receptors in osteoblastic cells, leading to decreased osteocalcin expression during vitamin D treatment (Jaiswal et al. 1997). The expression of collagen type I mRNA increased in the cells treated with osteoinductive medium, a result indicating the occurrence of osteodifferentiation in the bovine MSCs.

During osteogenesis in the first passage, the bovine MSCs lost the ability to form mineralized nodules; however, the potential to express osteocalcin and collagen type I mRNA was maintained. This modification in the manner of osteogenic phenotype expression does not necessarily imply that the cells lose their potential to differentiate. Satomura et al. (2000) have shown that the formation of mineralized nodules in vitro does not predict actual osteogenic capability in vivo because clonal lines of certain murine cells do not form nodules in culture but are able to form bone when transplanted into immunocompromised mice. However, the loss in their potential for differentiation during culturing could be attributed to several factors, including species character, cell isolation, and culture techniques, and conditions in the culture medium (Kadiyala et al. 1997; Sekiya et al. 2002; Digirolamo et al. 1999).

Close cell-to-cell contact and certain chondrogenic bioactive factors are widely accepted as being two main principles involved in enhancing chondrogenic differentiation. The best method to obtain strong cell-to-cell interaction is to culture MSCs in a pellet or micromass culture system (Johnstone et al. 1998; Jones et al. 2002). The bioactive factors that stimulate chondrogenesis include TGF- $\beta 1$, bone morphogenic protein, fibroblast growth factor, and insulin-like growth factor (Mastrogiacomo et al. 2001). TGF- $\beta 1$ acts via high-affinity interaction with a heteromeric receptor complex comprising two structurally-related serine-threonine kinases, the type I and II receptors, and transduces its signals through Smad proteins intracellularly (Miyazono 2000). In addition to the pellet and micromass culture systems, Worster et al. (2000a) have induced chondrogenesis in equine MSCs in monolayer culture by using TGF- $\beta 1$. We have reported the spontaneous chondrogenic differentiation of bovine MSCs, independent of exogenous bioactive substances, in a pellet culture system and thereby have confirmed the importance of culture conditions prior to chondrogenesis (Bosnakovski et al. 2004). In the present study, the potential of bovine MSCs to undergo chondrogenesis has been analyzed after treatment with TGF- $\beta 1$ in monolayer culture. The chondrogenic differentiation of MSCs in monolayer culture apears to be dose-dependent and timedependent in relation to TGF- $\beta 1$, despite its suppressive effect on chondrogenesis in pellet culture (Bosnakovski et al. 2004). In our system, TGF- $\beta 1$ induces increased collagen type II expression (14.2 times), which clearly demonstrates the chondrogenic effect of this factor. Cells cultured with no treatment with any bioactive substance do not express sox 9 , an early transcription factor of chondrogenesis. However, it is detectable after treatment with TGF- $\beta 1$. Sox 9 has been shown to regulate the rate of chondrocyte differentiation by controlling the expression of a series of chondrocyte-specific genes, including those for aggrecan and collagens type II, IX, and XI (De Crombrugghe 2000; Tchetina et al. 2003). In our previous study, the expression of chondrogenic genes was not observed in cells cultured in monolayer (Bosnakovski et al. 2004). However, with the improvement in the sensitivity of RT-PCR techniques, a basal level of gene expression of collagen type II and aggrecan was detected in MSCs cultured in medium containing FBS. A low level of gene expression of collagen type II has also been detected in untreated human and equine MSCs (Majumdar et al. 2000; Fortier et al. 1998; Worster et al. 2000a, 2000b). Moreover, murine bone marrow stromal cells express several markers that are characteristic of osteoblastic, chondrogenic, and adipogenic phenotypes at some point during the extended culture period; this suggests that individual stromal cells are inherently flexible with respect to phenotype and demonstrate the potential for plasticity (Satomura et al. 2000). The effect of TGF- $\beta 1$ on chondrocyte proliferation and the synthesis of extracellular matrix is contextual and may be stimulatory or inhibitory, depending on the stage of cellular differentiation, growth condition, and other factors (Glansbeek et al. 1993).

In addition to the promotion of chondrogenesis, TGF- $\beta 1$ also stimulates the proliferation of bovine MSCs in monolayer culture. This is evident even at a low concentration $(1 \mathrm{ng} / \mathrm{ml})$ after 3 days of stimulation. These results can be correlated with previously published 
reports on the stimulating effect of TGF- $\beta 1$ on chondrocytes and rat MSC proliferation (Qi and Scully 1998; Andrades et al. 1999); however, they are not in agreement with studies in which human MSCs have been used (Walsh at al. 2003). This could be attributable to species difference, the use of different doses of TGF- $\beta 1$, or differences in culture conditions.

Adipogenic differentiation was induced by using a combination of MIX and dexamethasone, a routinely used method to stimulate the differentiation of pre-adipocytes and stem cells. The mechanism of action of both stimulants is not completely understood; however, certain studies indicate that the effect is based on the mediation of cAMP metabolism (Gregoire et al. 1998). In our system, differentiation was apparent by the accumulation of lipid vacuoles within cells that developed, coalesced, and eventually filled the entire cell over a period of time. Increased expression of $\mathrm{aP} 2$ and PPAR- $\gamma 2$ was detected in these cells. PPAR- $\gamma 2$ is an adipocyte-specific gene belonging to the PPARs family, and together with $\mathrm{C} /$ EBP, is one of the transcription factors that are induced early during the differentiation of adipocytes (Rosen et al. 1999). AP2 is also an adipose-tissue-specific gene and is synthesized in the terminal phase of differentiation (Gregoire et al. 1998). In addition, we have confirmed an increased expression of lipoprotein lipase in treated cells (data not shown); however, this marker is not adipose-tissue-specific and is also synthesized by macrophages and other cells of mesenchymal origin (TengkuMuhammad et al. 1996). During the screening of adipogenesis, aP2 expression has been detected in uncommitted cells. This may be attributable to the minor contamination of cell cultures with pre-adipocytes and adipocytes or to spontaneous adipogenesis in cells in a state of growth arrest or may be characteristic of the cells of the species. The method of isolation of MSCs used in this study results in a cell culture composed of a heterogenic cell population. Cell clones from this type of culture are reported to grow into colonies with a wide range of sizes and morphologies at various proliferation rates and exhibit a potential for multilineage differentiation. Cells that spontaneously differentiate into osteocytes, adipocytes, or chondrocytes have also been detected in some colonies (Bianco et al. 2001).

A limitation of the present study is the use of an in vitro model that contains a heterogeneous population of cells. However, this well-documented system has been previously used for the confirmation of the presence of MSCs in cultures of bone marrow stromal cells from various species by inducing multilineage differentiation at the single cell level.

In conclusion, we have demonstrated that bovine MSCs, similar to corresponding cells from other species, exhibit high proliferation rates and multilineage differentiation potential. In addition, they can be easily harvested and isolated, thereby making them attractive tools for further studies into development and physiology and for clinical application.

\section{References}

Aerssens J, Boonen S, Lowet G, Dequeker J (1998) Interspecies differences in bone composition, density, and quality: potential implications for in vivo bone research. Endocrinology 139:663-670

Alvarez-Dolado M, Pardal R, Garcia-Verdugo JM, Fike JR, Lee HO, Pfeffer K, Lois C, Morrison SJ, Alvarez-Buylla A (2003) Fusion of bone-marrow-derived cells with Purkinje neurons, cardiomyocytes and hepatocytes. Nature 425:968-973

Andrades JA, Han B, Becerra J, Sorgente N, Hall FL, Nimni ME (1999) A recombinant human TGF-betal fusion protein with collagen-binding domain promotes migration, growth, and differentiation of bone marrow mesenchymal cells. Exp Cell Res 250:485-498

Bianco P, Riminucci M, Gronthos S, Robey PG (2001) Bone marrow stromal stem cells: nature, biology, and potential applications. Stem Cells 19:180-192

Bosnakovski D, Mizuno M, Kim G, Ishiguro T, Okumura M, Iwanaga T, Kadosawa T, Fujinaga T (2004) Chondrogenic differentiation of bovine mesenchymal stem cells in pellet cultural system. Exp Hematol 32:502-509

Bruder SP, Jaiswal N, Haynesworth SE (1997) Growth kinetics, selfrenewal, and the osteogenic potential of purified human mesenchymal stem cells during extensive subcultivation and following cryopreservation. J Cell Biochem 64:278-294

Bruder SP, Kurth AA, Shea M, Hayes WC, Jaiswal N, Kadiyala S (1998) Bone regeneration by implantation of purified, cultureexpanded human mesenchymal stem cells. J Orthop Res $16: 155-162$

Chen TL (2004) Inhibition of growth and differentiation of osteoprogenitors in mouse bone marrow stromal cell cultures by increased donor age and glucocorticoid treatment. Bone 35:83-95

De Crombrugghe B, Lefebvre V, Behringer RR, Bi W, Murakami S, Huang W (2000) Transcriptional mechanisms of chondrocyte differentiation. Matrix Biol 19:389-394

De Jong DS, Vaes BL, Dechering KJ, Feijen A, Hendriks JM, Wehrens R, Mummery CL, Zoelen EJ van, Olijve W, Steegenga WT (2004) Identification of novel regulators associated with early-phase osteoblast differentiation. J Bone Miner Res 19:947-958

Digirolamo CM, Stokes D, Colter D, Phinney DG, Class R, Prockop DJ (1999) Propagation and senescence of human marrow stromal cells in culture: a simple colony-forming assay identifies samples with the greatest potential to propagate and differentiate. Br J Haematol 107:275-281

Fortier LA, Nixon AJ, Williams J, Cable CS (1998) Isolation and chondrocytic differentiation of equine bone marrow-derived mesenchymal stem cells. Am J Vet Res 59:1182-1187

Frankel MS (2000) In search of stem cell policy. Science 287:1397

Friedenstein AJ, Gorskaja JF, Kulagina NN (1976) Fibroblast precursors in normal and irradiated mouse hematopoietic organs. Exp Hematol 4:267-274

Glansbeek HL, Kraan PM van der, Vitters EL, Berg WB van den (1993) Correlation of the size of type II transforming growth factor beta (TGF-beta) receptor with TGF-beta responses of isolated bovine articular chondrocytes. Ann Rheum Dis 52:812-816

Goodell MA (2003) Stem-cell "plasticity": befuddled by the muddle. Curr Opin Hematol 10:208-213

Gregoire FM, Smas CM, Sul HS (1998) Understanding adipocyte differentiation.Physiol Rev 78:783-809

Gronthos S, Simmons PJ (1995) The growth factor requirements of STRO-1-positive human bone marrow stromal precursors under serum-deprived conditions in vitro. Blood 85:929-940

Heng BC, Cao T, Haider HK, Wang DZ, Sim EK, Ng SC (2004) An overview and synopsis of techniques for directing stem cell differentiation in vitro. Cell Tissue Res 315:291-303

Holzer G, Einhorn TA, Majeska RJ (2002) Estrogen regulation of growth and alkaline phosphatase expression by cultured human bone marrow stromal cells. J Orthop Res 20:281-288 
Ianus A, Holz GG, Theise ND, Hussain MA (2003) In vivo derivation of glucose-competent pancreatic endocrine cells from bone marrow without evidence of cell fusion. J Clin Invest 111:843-850

Jaiswal N, Haynesworth SE, Caplan AI, Bruder SP (1997) Osteogenic differentiation of purified, culture-expanded human mesenchymal stem cells in vitro. J Cell Biochem 64:295-312

Janderova L, McNeil M, Murrell AN, Mynatt RL, Smith SR (2003) Human mesenchymal stem cells as an in vitro model for human adipogenesis. Obes Res 11:65-74

Jiang Y, Jahagirdar BN, Reinhardt RL, Schwartz RE, Keene CD, Ortiz-Gonzalez XR, Reyes M, Lenvik T, Lund T, Blackstad M, $\mathrm{Du}$ J, Aldrich S, Lisberg A, Low WC, Largaespada DA, Verfaillie CM (2002a) Pluripotency of mesenchymal stem cells derived from adult marrow. Nature 418:41-49

Jiang Y, Vaessen B, Lenvik T, Blackstad M, Reyes M, Verfaillie CM (2002b) Multipotent progenitor cells can be isolated from postnatal murine bone marrow, muscle, and brain. Exp Hematol 30:896-904

Johnstone B, Hering TM, Caplan AI, Goldberg VM, Yoo JU (1998) In vitro chondrogenesis of bone marrow-derived mesenchymal progenitor cells. Exp Cell Res 238:265-272

Jones EA, Kinsey SE, English A, Jones RA, Straszynski L, Meredith DM, Markham AF, Jack A, Emery P, McGonagle D (2002) Isolation and characterization of bone marrow multipotential mesenchymal progenitor cells. Arthritis Rheum 46:3349-3360

Kadiyala S, Young RG, Thiede MA, Bruder SP (1997) Culture expanded canine mesenchymal stem cells possess osteochondrogenic potential in vivo and in vitro. Cell Transplant 6:125134

Kim YJ, Sah RL, Doong JY, Grodzinsky AJ (1988) Fluorometric assay of DNA in cartilage explants using Hoechst 33258. Anal Biochem 174:168-176

Kon E, Muraglia A, Corsi A, Bianco P, Marcacci M, Martin I, Boyde A, Ruspantini I, Chistolini P, Rocca M, Giardino R, Cancedda R, Quarto R (2000) Autologous bone marrow stromal cells loaded onto porous hydroxyapatite ceramic accelerate bone repair in critical-size defects of sheep long bones. J Biomed Mater Res 49:328-337

Lagasse E, Connors H, Al-Dhalimy M, Reitsma M, Dohse M, Osborne L, Wang X, Finegold M, Weissman IL, Grompe M (2000) Purified hematopoietic stem cells can differentiate into hepatocytes in vivo. Nat Med 6:1229-1234

Liu Y, Chen F, Liu W, Cui L, Shang Q, Xia W, Wang J, Cui Y, Yang G, Liu D, Wu J, Xu R, Buonocore SD, Cao Y (2002) Repairing large porcine full-thickness defects of articular cartilage using autologous chondrocyte-engineered cartilage. Tissue Eng 8:709-721

Majumdar MK, Banks V, Peluso DP, Morris EA (2000) Isolation, characterization, and chondrogenic potential of human bone marrow-derived multipotential stromal cells. J Cell Physiol 185:98-106

Martin DR, Cox NR, Hathcock TL, Niemeyer GP, Baker HJ (2002) Isolation and characterization of multipotential mesenchymal stem cells from feline bone marrow. Exp Hematol 30:879-886

Mastrogiacomo M, Cancedda R, Quarto R (2001) Effect of different growth factors on the chondrogenic potential of human bone marrow stromal cells. Osteoarthritis Cartilage 9 (Suppl A):S36S40

Miyazono K (2000) Positive and negative regulation of TGF-beta signaling. J Cell Sci 113:1101-1109

Mizuno M, Fujisawa R, Kuboki Y (2000) Type I collagen-induced osteoblastic differentiation of bone-marrow cells mediated by collagen-alpha2beta1 integrin interaction. J Cell Physiol 184:207-213

Orlic D, Kajstura J, Chimenti S, Jakoniuk I, Anderson SM, Li B, Pickel J, McKay R, Nadal-Ginard B, Bodine DM, Leri A, Anversa P (2001) Bone marrow cells regenerate infarcted myocardium. Nature 410:701-705
Pittenger MF, Mackay AM, Beck SC, Jaiswal RK, Douglas R, Mosca JD, Moorman MA, Simonetti DW, Craig S, Marshak DR (1999) Multilineage potential of adult human mesenchymal stem cells. Science 284:143-147

Qi WN, Scully SP (1998) Effect of type II collagen in chondrocyte response to TGF-beta 1 regulation. Exp Cell Res 241:142-150

Reyes M, Lund T, Lenvik T, Aguiar D, Koodie L, Verfaillie CM (2001) Purification and ex vivo expansion of postnatal human marrow mesodermal progenitor cells. Blood 98:2615-2625

Ringe J, Kaps C, Schmitt B, Buscher K, Bartel J, Smolian H, Schultz O, Burmester GR, Haupl T, Sittinger M (2002) Porcine mesenchymal stem cells. Induction of distinct mesenchymal cell lineages. Cell Tissue Res 307:321-327

Rodic N, Rutenberg MS, Terada N (2004) Cell fusion and reprogramming: resolving our transdifferences. Trends Mol Med 10:93-96

Rosen ED, Sarraf P, Troy AE, Bradwin G, Moore K, Milstone DS, Spiegelman BM, Mortensen RM (1999) PPAR gamma is required for the differentiation of adipose tissue in vivo and in vitro. Mol Cell 4:611-617

Satomura K, Krebsbach P, Bianco P, Gehron Robey P (2000) Osteogenic imprinting upstream of marrow stromal cell differentiation. J Cell Biochem 78:391-403

Sekiya I, Larson BL, Smith JR, Pochampally R, Cui JG, Prockop DJ (2002) Expansion of human adult stem cells from bone marrow stroma: conditions that maximize the yields of early progenitors and evaluate their quality. Stem Cells 20:530-541

Tchetina E, Mwale F, Poole AR (2003) Distinct phases of coordinated early and late gene expression in growth plate chondrocytes in relationship to cell proliferation, matrix assembly, remodeling, and cell differentiation. J Bone Miner Res 18:844-851

Tengku-Muhammad TS, Hughes TR, Cryer A, Ramji DP (1996) Differential regulation of lipoprotein lipase in the macrophage J774.2 cell line by cytokines. Cytokine 8:525-533

Toma JG, Akhavan M, Fernandes KJ, Barnabe-Heider F, Sadikot A, Kaplan DR, Miller FD (2001) Isolation of multipotent adult stem cells from the dermis of mammalian skin. Nat Cell Biol $3: 778-784$

Vassilopoulos G, Wang PR, Russell DW (2003) Transplanted bone marrow regenerates liver by cell fusion. Nature 422:901-904

Wagers AJ, Weissman IL (2004) Plasticity of adult stem cells. Cell 116:639-648

Wagers AJ, Sherwood RI, Christensen JL, Weissman IL (2002) Little evidence for developmental plasticity of adult hematopoietic stem cells. Science 297:2256-2259

Wakitani S, Goto T, Pineda SJ, Young RG, Mansour JM, Caplan AI, Goldberg VM (1994) Mesenchymal cell-based repair of large, full-thickness defects of articular cartilage. J Bone Joint Surg Am 76:579-592

Wakitani S, Imoto K, Yamamoto T, Saito M, Murata N, Yoneda M (2002) Human autologous culture expanded bone marrow mesenchymal cell transplantation for repair of cartilage defects in osteoarthritic knees. Osteoarthritis Cartilage 10:199-206

Walsh S, Jefferiss C, Stewart K, Beresford JN (2003) TGF betal limits the expansion of the osteoprogenitor fraction in cultures of human bone marrow stromal cells. Cell Tissue Res 311:187198

Wang WG, Lou SQ, Ju XD, Xia K, Xia JH (2003) In vitro chondrogenesis of human bone marrow-derived mesenchymal progenitor cells in monolayer culture: activation by transfection with TGF-beta2. Tissue Cell 35:69-77

Weimann JM, Johansson CB, Trejo A, Blau HM (2003) Stable reprogrammed heterokaryons form spontaneously in Purkinje neurons after bone marrow transplant. Nat Cell Biol 5:959-966

Woodbury D, Schwarz EJ, Prockop DJ, Black IB (2000) Adult rat and human bone marrow stromal cells differentiate into neurons. J Neurosci Res 61:364-370

Worster AA, Nixon AJ, Brower-Toland BD, Williams J (2000a) Effect of transforming growth factor beta1 on chondrogenic differentiation of cultured equine mesenchymal stem cells. Am J Vet Res 61:1003-1010 
Worster AA, Brower-Toland BD, Fortier LA, Bent SJ, Williams J, Nixon AJ (2000b) Chondrocytic differentiation of mesenchymal stem cells sequentially exposed to transforming growth factor-beta1 in monolayer and insulin-like growth factor-I in a three-dimensional matrix. J Orthop Res 19:738-7499
Wurmser AE, Nakashima K, Summers RG, Toni N, D'Amour KA, Lie DC, Gage FH (2004) Cell fusion-independent differentiation of neural stem cells to the endothelial lineage. Nature 430:350-356

Zuk PA, Zhu M, Ashjian P, De Ugarte DA, Huang JI, Mizuno H, Alfonso ZC, Fraser JK, Benhaim P, Hedrick MH (2002) Human adipose tissue is a source of multipotent stem cells. Mol Biol Cell 13:4279-4295 